\title{
ホスファチジルセリンはエンドソームを介した物質輸送に必須である リン脂質の新規機能
}

ホスファチジルセリン（phosphatidylserine;PS）は 極性頭部にセリン残基をもつグリセロリン脂質である (図 1A). 真核細胞の膜の $5 \sim 10 \%$ を構成し，特に細胞 膜の細胞質側に濃縮して存在することが知られている. 細胞膜におけるPSの機能として，（1）細胞死に伴い細 胞外に露出し, 死細胞の貪食を誘起する “eat-me” シグ ナルとして機能すること, (2) カルシウムイオン, ジア シルグリセロールと協調してプロテインキナーゼCを細 胞膜へ移行・活性化すること，などがよく知られてい る(1). これら細胞膜における機能に加えて, 細胞内に存 在するPSの機能が近年になり明らかにされてきた。本 稿では, 特に細胞内物質輸送に必須な細胞内PSに関し ての最新の知見を紹介する.

エンドサイトーシスによって細胞内に取り达まれた細 胞膜上または外界の物質のたどる経路には，（1）リソ ソームへ運ばれ分解を受ける経路／分解経路，(2) 細胞 膜へ戻る経路/リサイクル経路，（3）ゴルジ体へ運ばれ る経路／逆行性輸送経路の3 種類がある. 分解経路に乗 る代表的な因子にEGFR（上皮成長因子受容体）があ
る，EGFを細胞膜上で結合し活性化したEGFRは，初 期エンドソームから後期エンドソームへ，次いでリソ ソームへ運搬されることで分解を受ける。 このシステム は，活性化された増殖因子受容体から増殖シグナルが出 続けることによって細胞が過増殖することを防ぐための 重要な細胞増殖の負の調節機構である。初期エンドソー ムからリサイクリングエンドソーム（REs）を経て細胞 膜へとリサイクルされる代表的な分子に，トランスフェ リン受容体がある。上述の分解経路と対照的に，受容体 の合成を新規に行うことなしにリガンド分子（トランス フェリン）を繰り返し取り込むことができるというメ リットがある。

近年, PSに高い特異性をもつタンパク質性の可視化 プローブ (lactadherinタンパク質のC2 ドメインに GFP を結合させた融合タンパク質）が報告された ${ }^{(2)}$. lactC2GFPを細胞質中に発現することによって細胞質側のPS を可視化したところ, 小胞体, ゴルジ体，ミトコンドリ アなどPSの合成／代謝／運搬に関与している細胞小器 官で予想に反して局在が認められず，その一方でエンド

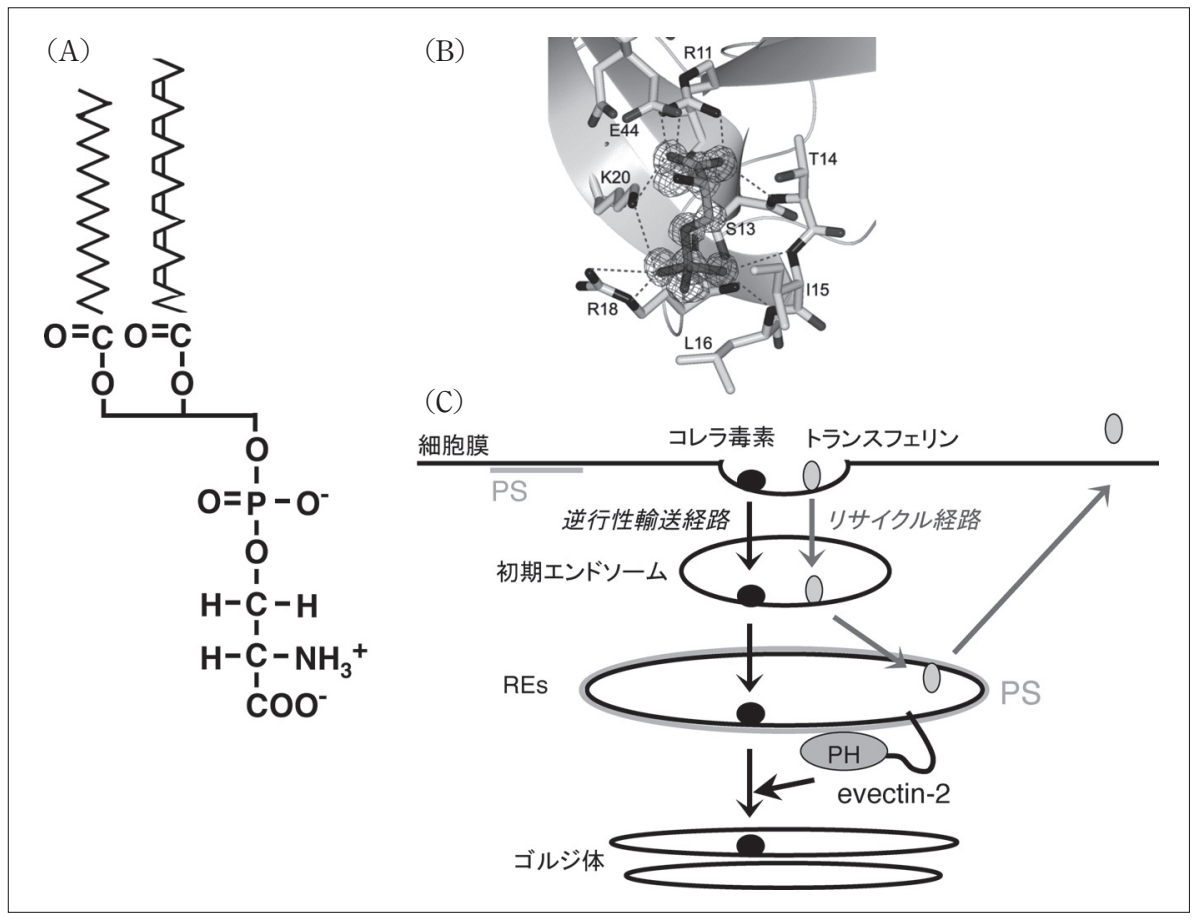

図1・PSを認識するタンパク質 evectin-2

(A) PSはグリセロ骨格をもつリン脂 質であり，極性頭部にセリン残基を もつ. (B) ヒト由来 evectin-2のPH ドメインのO-ホスホ-L-セリン結合領 域. O-ホスホ-L-セリンの電子密度 $(\sigma \mathrm{A}$-weighted $\mathrm{F} o-\mathrm{F} c$ omit map ; $3.0 \sigma$ ) をメッシュで示す．水素結合と塩橋 を破線で示す。（C) evectin-2はPH ドメインによってREsに局在し、 REsからゴルジ体への逆行性輸送 （例：コレラ毒素）を制御する。リサ イクル経路（トランスフェリン）に は関与しない。 


\section{今日の話題}

ソームと細胞膜に強い局在が認められた。彼らは続報に おいて，エンドソームでも特にREsに強いPSの局在を 認めたとしている(3).

Evectin-2 は, N末端にPH (pleckstrin homology) ド メイン（100～120アミノ酸から構成される領域で，ホ スファチジルイノシトールリン酸に結合する）をもち, C末端に膜貫通領域をもつ約 220 アミノ酸から構成され るタンパク質である。内田らは，(1) evectin-2がREs に局在すること，(2) evectin-2 PHがホスファチジルイ ノシトールリン酸でなくPSを特異的に認識すること, （3）O-ホスホセリンとの共結晶をX 線構造解析すること で,リガンド認識に必要なアミノ酸残基を特定（図 1B)，（4）REsの細胞質側に豊富に存在するPSを evectin-2 PHが認識することで evectin-2がREsに局在する ことを明らかにした ${ }^{(4)}$ 。この結果は, Grinsteinらの lactC2-GFPを用いた結果 ${ }^{(3)}$ と合致している.

Evectin-2のノックダウンにより，ゴルジ体に逆行性 輸送経路によって運ばれるコレラ毒素の輸送がREsで 大幅に遅滞するが，トランスフェリンのリサイクル経路 には影響が認められない。 また, 逆行性輸送経路を使っ てゴルジ体局在を維持しているタンパク質（TGN46と GP73）のゴルジ体局在が失われる．このことから，内 田らは evectin-2がREsからゴルジ体へ向かう逆行性輸 送経路の特異的な制御因子であると結論している ${ }^{(4)}$ (図 1C). PSが単なる生体膜の構成脂質として存在するの ではなく, PS 結合タンパク質を通じて細胞機能を発揮 していることを示したことに意義がある.

李らはPS生合成能力が低下している $\mathrm{CHO}$ 細胞変異株 で, TGN38（TGN46と同じく逆行性輸送経路を使って ゴルジ体局在を維持しているタンパク質）のゴルジ体局 在が失われており，それは逆行性輸送経路の特異的な阻 害に起因することを示している ${ }^{(5)}$.さらに，培地へのエ タノールアミン（PS合成前駆体）の添加によってこの 異常が回復することから, PSの減少と逆行性輸送経路 阻害の因果関係を明確に示している.

酵母（Saccharomyces cerevisiae）においてもPSの機 能が明らかにされてきている. Grinsteinのグループは lactC2-GFPを用いることで, 酵母の出芽部位を構成す る細胞膜にPSが特に濃縮して存在することを示した ${ }^{(6)}$. 種々の分泌経路に異常をもつ温度感受性変異細胞 $\left(\sec 1^{t s}, \sec 6^{t s}, \sec 7^{t s}\right.$ 細胞) を用いることによって，こ の出芽部位におけるPSの濃縮がゴルジ体からの分泌経
路によって形成・維持されていることを示唆した. $\sec 1^{t s}, \sec 6^{t s}$ 細胞では非許容温度培養下で出芽部位への PSの濃縮は認められなくなり, その一方で出芽部位の 細胞質部分にPSが蓄積する。これは，ゴルジ体から分 泌されたPSを含む輸送小胞が出芽部位を構成する細胞 膜に融合することができず，その直下の細胞質部分に蓄 積してしまったものと解釈できる.

彼らは, このPSの出芽部位での濃縮パターンが Cdc42p（細胞極性の制御因子）の局在と酷似している ことに着目して, PSとCdc42pの関係について研究を進 めた. PSの生合成酵素を欠損しているcholA細胞では, （1）出芽形成率が野生株と比較して非常に悪いこと, （2）出芽をしている細胞で Cdc42p の局在を見てみると 出芽部位へのCdc42pの局在が完全に失われているこ と，（3）培地にlysoPS（細胞内に取り込まれたのちに PSへと代謝される）を添加することによって出芽形成 率が上昇し, Cdc42p の出芽部位への局在が回復するこ と，を明らかにした。Cdc42pはC末端に正電荷をもつ アミノ酸残基がクラスターを形成している.PSと Cdc42pが静電的な相互作用をすることで, PSの極性を もった分布がCdc42pの極性化を制御している可能性が 考えられる.

Evectin-2の同定およびPS特異的な可視化プローブ (lactC2, evectin2-PH) の開発を通じて, 細胞内PSの分 布と機能が哺乳細胞で明らかにされてきた。酵母におい ては細胞小器官におけるPSの存在は可視化されていな いが (これは量的な問題と考えられる)，それにもかか わらずPSの欠損により，細胞内物質輸送を介した細胞 極性形成／出芽に異常が出ることは興味深い。細胞質に は evectin- 2 やCdc 42 p 以外にも未同定の多様な PS 結合 タンパク質が存在し，哺乳細胞では特にREsを介した 膜輸送経路を制御することで多彩な細胞現象を制御して いる可能性が考えられる.

1) P. A. Leventis \& S. Grinstein: Annu. Rev. Biophys., 39, 407 (2010).

2) T. Yeung, G. E. Gilbert, J. Shi, J. Silvius, A. Kapus \& S. Grinstein : Science, 319, 210 (2008).

3) G. D. Fairn, N. L. Schieber, N. Ariotti, S. Murphy, L. Kuerschner, R. I. Webb, S. Grinstein \& R. G. Parton:J. Cell Biol., 194, 257 (2011).

4) Y. Uchida, J. Hasegawa, D. Chinnapen, T. Inoue, S. Okazaki, R. Kato, S. Wakatsuki, R. Misaki, M. Koike, Y. Uchiyama et al. : Proc. Natl. Acad. Sci. USA, 108, 15846 (2011).

5) S. Lee, Y. Uchida, K. Emoto, M. Umeda, O. Kuge, T. Ta- 


\section{今日の話題}

guchi \& H. Arai: Genes Cells, 17, 728 (2012).

6) G. D. Fairn, M. Hermansson, P. Somerharju \& S. Grinstein : Nat. Cell Biol., 13, 1424 (2011).

(田口友彦, 東京大学大学院薬学系研究科)
プロフィル

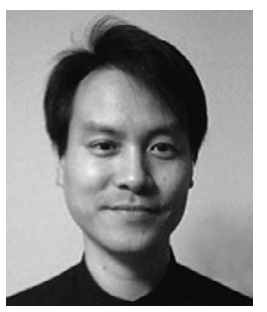

田口 友彦 (Tomohiko TAGUCHI)

$<$ 略歴 $>1992$ 年東京大学理学部生物化学 科卒業 $/ 1997$ 年同大学大学院理学系研究 科修了, 理学博士 /理化学研究所基礎科学 特別研究員, 日本学術振興会海外特別研究 員 (エール大学医学部細胞生物学部門), 大阪大学大学院医学系研究科特任准教授な どを経て, 現職＜研究テーマと抱負 > 物質 のリサイクルを物質の分解と対比しながら 理解していきたい。特に，リサイクリング エンドソームの構造と機能を, 細胞生物 学／生化学的手法を使って明らかにしてい きたいと思っています＜趣味＞酒蔵巡り, 愛犬と遊ぶこと 